\title{
A terminological matter: paragenesis, antigravitative erosion or antigravitational erosion?
}

\author{
Giancarlo Pasini ${ }^{1}$
}

\begin{abstract}
:
Pasini G. 2009. A terminological matter: paragenesis, antigravitative erosion or antigravitational erosion ? International Journal of Speleology, 38(2), 129-138. Bologna (Italy). ISSN 0392-6672.

In the speleological literature three terms are utilized to designate the "ascending erosion": paragenesis (= paragénésis, coined in 1968), antigravitative erosion (= erosione antigravitativa, coined in 1966) and antigravitational erosion (wrong English translation of the Italian term erosione antigravitativa, utilized later on). The term paragenesis should be abandoned because of the priority of the term erosione antigravitativa - on the ground of the "law of priority" - and because of its ambiguous etimology. On the other hand, the term antigravitational erosion should be forsaken in favour of the term antigravitative erosion, given the meaning that the terms gravitation and gravity have in Physics. Therefore, to designate the phenomenon of the "ascending erosion" there would be nothing left but the term antigravitative erosion.

The antigravitative erosion process and its recognizability are illustrated.

Examples of caves with evident antigravitative erosion phenomena, developed in different karstifiable rocks and in several parts of the world, are given.

It is recalled that the antigravitative erosion is a phenomenon well-known since 1942 and widely proven and supported, and that it is relatively easy - in many cases - to recognize the antigravitative origin of karstic passages.

It is stressed that the antigravitative erosion is an important phenomenon, exclusive of the karstic caves and unique in nature.
\end{abstract}

Keywords: speleogenesis, paragenesis, syngenesis, antigravitative erosion, antigravitational erosion.

\section{ON THE USAGE OF THE TERMS SYNGENESIS, PARAGENESIS, ANTIGRAVITATIVE EROSION ( LATO SENSU) AND ANTIGRAVITATIONAL EROSION}

"....Man gibt zuerst in Worten nach, und dann allmählich auch in der Sache...” (Freud, 1921). [ One gives way first in words, and then little by little in substance too ].

\section{Antigravitative erosion and Antigravitational erosion}

Subterraneous waters circulating under pressure in small or big phreatic tubes are often forced - by the sediments piled up on their bottoms, which protect

\footnotetext{
1. Istituto di Scienze Marine (I.S.MAR.), Geologia Marina, del Consiglio Nazionale delle Ricerche (C.N.R.), Bologna (Italy) Istituto Italiano di Speleologia (Sezione dell'Istituto di Geologia e Paleontologia dell'Università di Bologna, Italy) - Società Speleologica Italiana - Gruppo Speleologico Bolognese del Club Alpino Italiano - Postal address: G. Pasini, Via Ranzani 13/5, 40127 Bologna, Italy. Tel.: +39 - 51 - 242120. E-mail address: giancarlopasini@alice.it
}

them from further corrosion and erosion - to flow at ever higher levels, carving only the ceilings and the upper walls of the tubes (see Fig. 1).

Such a process, discovered by Philippe Renault (1958), is termed erosione antigravitativa by Pasini 1966 (pp. 53-55), 1967b (in the title) and 1975 (in the title), in that it acts in opposite direction to the force of gravity (ávti means opposite, against, in ancient Greek: cf. Liddell, Scott and Jones 1940, p. 153). The term erosione (= erosion) is here used lato sensu, i.e. in its wider meaning (cf. Howell, 1957, Hole, 1968, Monkhouse, 1970, Goudie, 2004), which includes both mechanical erosion through the action of streams (usually carrying debris: erosion stricto sensu), and the physical dissolution (for example, that which concerns sulphates and chlorides), and the chemical dissolution or corrosion stricto sensu (that of limestones and dolomites). Obviously, for the development of the process of antigravitative erosion it is necessary that the detrital floors of the passages be altogether less erodible (lato sensu) than the bedrock. The term "antigravitative" is here employed in a meaning which has no connection with the physical concept of "antiGravity". The above-mentioned process is called paragenesis by all other Authors who mentioned it 


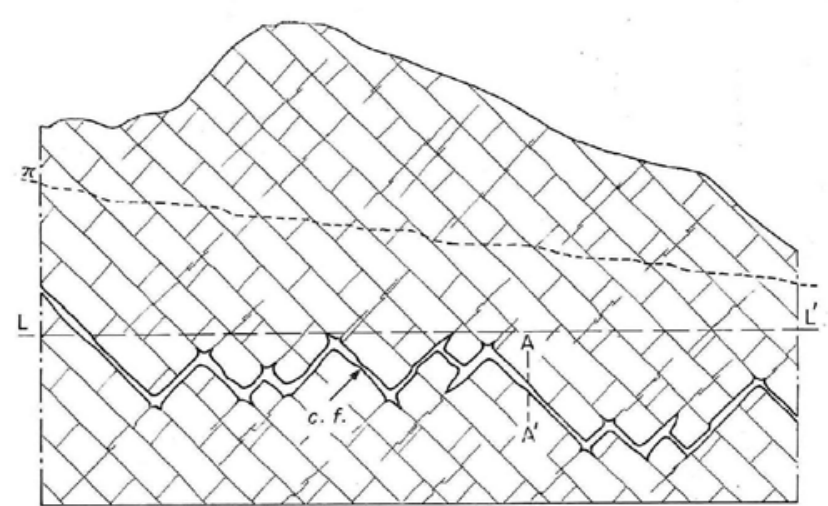

a)

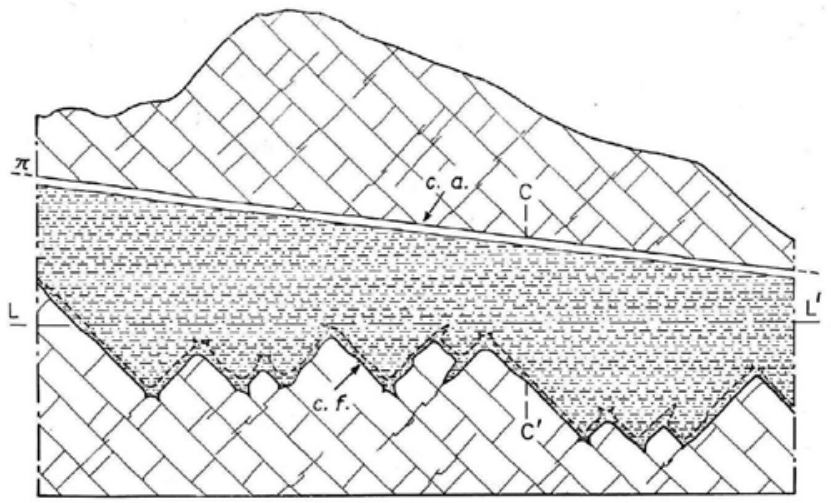

c)

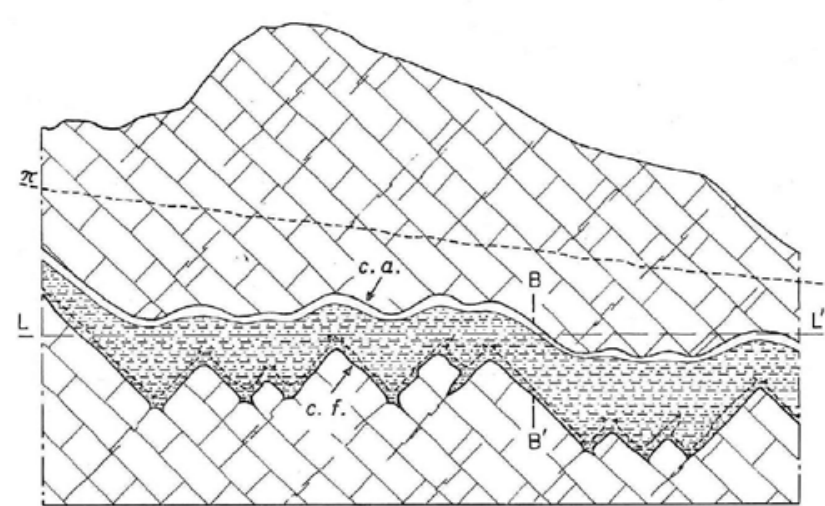

b)

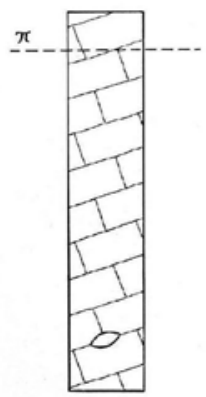

Sez. A A'

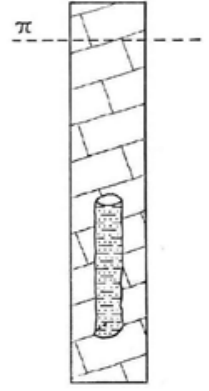

Sez, B B'

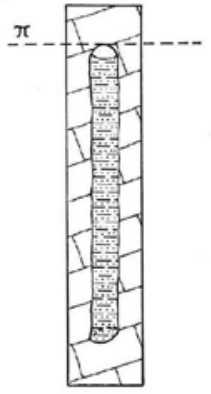

Sez. C C'
G. Pasini 1967

Fig. 1 - Evolutive scheme of an antigravitative cave in fractured karstifiable rocks (from Pasini, 1967b,1975). The alternate rows of broken lines and dots represent clayey-silty sediments.

Fig. 1a represents, in long section, a stretch of a normal system of phreatic tubes, developed along bedding planes and joint planes. Figs. $1 \mathrm{~b}$ and 1c show the evolution of such galleries in an intermediate phase and at the end of the antigravitative erosion process, respectively : the phreatic tubes are compelled to develop upwards by antigravitative erosion because of the ever-growing sedimentary filling, which forces the underground canalized streams to erode only the conduits ceilings and upper walls and to flow at ever higher levels, until the piezometric surface is reached. $\pi$ = trace of the piezometric surface ; $L$ L' = local base level; c.f. = system of phreatic tubes; c.a. = system of antigravitative pseudo - 'phreatic tubes' (Pasini,1975, p. 297). Sez. AA', BB' and CC' = cross-sections of a segment of the cave during its evolution (the cross-sections are twice the size of the long sections).

(e.g.: Renault, 1968, who coined - as far as the caves originated from the true karstic phenomenon are concerned - the attribute paragénétique; Ford and Ewers, 1978; Lauritzen and Lauritsen, 1995; Frumkin, 1998; Ford, 2000; Farrant, 2004; Lundberg, 2005; Veni, 2005; Šušteršič, 2006; Ford and Williams, 2007). Some English-speaking Authors (e.g.: Ford, 2000; Ford and Williams, 2007), while adopting the term paragenesis, quoted also the term antigravitative erosion; other Authors (e.g.: Lundberg, 2005; Šušteršič, 2006) recalled the term coined by me in 1966, but mentioned it as antigravitational erosion.

But antigravitativeis not the same as antigravitational. The terms gravity and gravitation are mostly interchangeable in everyday use, but there is a definite difference between the two terms. Gravitation is the attractive force existing between any two objects having mass; the force of gravitation pulls objects together. Gravity is the gravitational force that occurs between the Earth and other bodies (including - obviously the running waters, that tend to carve the Earth rocks downwards); gravity is the force acting to pull objects toward the Earth, and constitutes a particular case of gravitation (S. Bergia, S. Braibant and P. Giacomelli, personal communication, November 2008).

Therefore, the attribute antigravitative should be preferred to the attribute antigravitational as far as the ascending erosion is concerned.

The misuse of the term antigravitational was actually caused by an error in the English Abstracts of my papers issued in 1967 (b) and 1975: the colleague who kindly wrote those Abstracts for me by translating into English my Italian "Riassunto" rendered - by mistake - the Italian word antigravitativa into the English word antigravitational, and I didn't realize it at first. I apologize for this error in my papers. So it happened that some English-speaking Authors quoted the wrong term (antigravitational erosion) from my English Abstracts tout court, probably because they had difficulty in reading both the Italian text and the figure captions and the Italian "Riassunto" of my two above mentioned papers (but the term "erosione antigravitativa" is present also in their titles); other Authors quoted - in a more scientific way - the right term.

Therefore, the alternative is actually between the terms paragenesis and antigravitative erosion.

First of all, in my opinion, the term "erosione 
antigravitativa" should be preferred-under the "law of priority" - because it was coined in 1966 and recalled in 1967, while the term "paragénesis" (or - more exactly the attribute "paragénétique") was coined in 1968 (see above). But the terms paragénesis, paragénétique and their translations should be abandoned also for other important reasons, which will be illustrated in the following chapter.

\section{The incorrect use of the terms syngenesis and paragenesis as speleogenetic processes in karstic caves}

\section{Utilization of the terms syngenesis and syngenetic in speleological literature}

The terms syngenesis and syngenetic derive from the classical Greek words oúv = with, contemporaneous

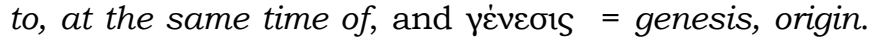
Syngenesis means: contemporaneous genesis, contemporaneous origin; syngenetic means: which has an origin contemporaneous to. So, in speleology, syngenetic cave means: primary cave, "Cave developed simultaneously with the enclosing rock" (Krause 1999, lemma 885), "Cavité formée lors du dépôt des roches qui la contiennent. On distingue des cavités volcaniques (par l'expansion des gaz: "grottes bulle", par l'écoulement de la lave : cavité rhéogénétique) et des cavités sédimentaires primaires (grottes de récif, cavités dans le tuf ou le travertin)" (Krause 1999, lemma 885) [Cave originated at the time of the formation of the rock which contains it. There are volcanic caves (due to the expansion of gas: "bubble caves"; due to the flow of lava: "rheogenetic" caves), and primary sedimentary caves (reef caves, caves in tuffs or in travertine) ]. There are syngenetic caves also in eolian calcarenites, “... where lithification and karstification of a sand-dune may proceed simultaneously." (Monroe, 1970).

But the "galeries syngénétiques" of Renault (1968, p. 575) are normal phreatic passages of karstic caves. Now which kind of contemporaneity could be imagined for these galleries, or for the syngenetic passages described by some English-speaking Authors?

So, in my opinion, the terms syngénesis and syngénétique in the meaning of Renault (1968) and their equivalents in other languages - should be forsaken, because these terms have been currently utilized by several Authors to name cavities developed contemporaneously with the host rock formation.

\section{Utilization of the terms paragenesis and paragenetic in speleological literature}

The speleogenetic terms paragenesis and paragenetic derive from the classical Greek words пара = alongside of, beside, by, to the side of, beyond, aside ( also in composition), and үغ่veors = genesis, origin. Paragenesis and paragenetic are thus at least ambiguous terms, for three reasons: a) because of the different meanings that пара can take; b) because none of these meanings seems to express the concept of "upwards development" (in classical Greek,

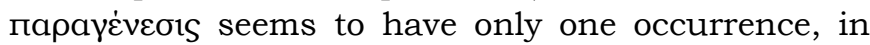
Epicurus [quoted by Eustathius, 111, 25: cf. Liddell,
Scott and Jones, 1940, p. 1306], with the meaning of "presence"); c) because paragenesis and paragenetic, utilized in contrapposition to syngenesis and syngenetic (which here have a temporal meaning), seem to replace the more correct - in this case - terms epigenesis and epigenetic (= subsequent : cf. Liddell, Scott and Jones 1940, p. 627, lemma énıүiүvoua1, I). If, on the other hand, Renault (1968, p. 580) intended to do an erudite translation of the French term remontant ("galerie paragénétique ou de creusement remontant"), also in this case the term epigenetic could be employed, to mean "upwards development" (દ́ni, in composition, also = upon or over [denoting motion]: cf. Liddell, Scott and Jones 1940, p. 623).

Therefore, the terms paragenesis and paragenetic should be refused also for etimological reasons.

The best term to describe the ascending erosion in the karstic caves is - in my opinion - "antigravitative erosion", and the attribute for the speleoforms generated by this kind of erosion should be "antigravitative" (e.g.: antigravitative gallery, antigravitative canyon; antigravitative ceiling channel, etc.).

By the way, I recall that the hypogean passages enlarged downwards by the normal erosion of a stream, which carved the floor of pre-existent galleries leaving intact their ceiling, are named Gravitationsgänge by Kyrle (1923), gallerie gravitazionali by Maucci (1952) and condotti gravitativi by other Italian Authors; thus, by analogy, the passages mentioned above, enlarged upwards by an erosive process that engraved the ceilings of pre-existing galleries leaving intact their floor, can be named - also for this reason - antigravitative passages, and the erosion which developed them antigravitative erosion.

\section{THE ANTIGRAVITATIVE EROSION PROCESS}

If in a phreatic passage sedimentation does not take place, the erosion lato sensu will act on the whole outer edge (vault, walls and floor) of the passage; so it will expand continuously, tending generally to acquire an elliptical or circular cross-section. These passages are named by Renault (1968, p. 576) - in my opinion incorrectly (see above) - galeries syngénétiques. In such passages the bedrock is visible in all points of the cross-sections, unless post-phreatic sedimentation occurred.

If, on the contrary, in the phreatic (or epiphreatic) passage there is sedimentation, the lower portion of the passage will be progressively covered by sediments of ever-increasing thickness ("filling"). These sediments will shield the lower part of the passage from a further erosion lato sensu, and the passage will enlarge only upwards (antigravitative erosion: Figs. 1 and 2a, b); in other words, the erosion lato sensu will affect only the vault and sometimes the uppermost parts of the passage's walls, giving origin to an antigravitative passage ( although it was demonstrated that very small dissolution occurs also in the lower portion of the passage, under the filling [Farrant, 2004] ). Obviously, in the antigravitative passages - not modified afterwards by vadose streams - the bedrock is visible only in the 


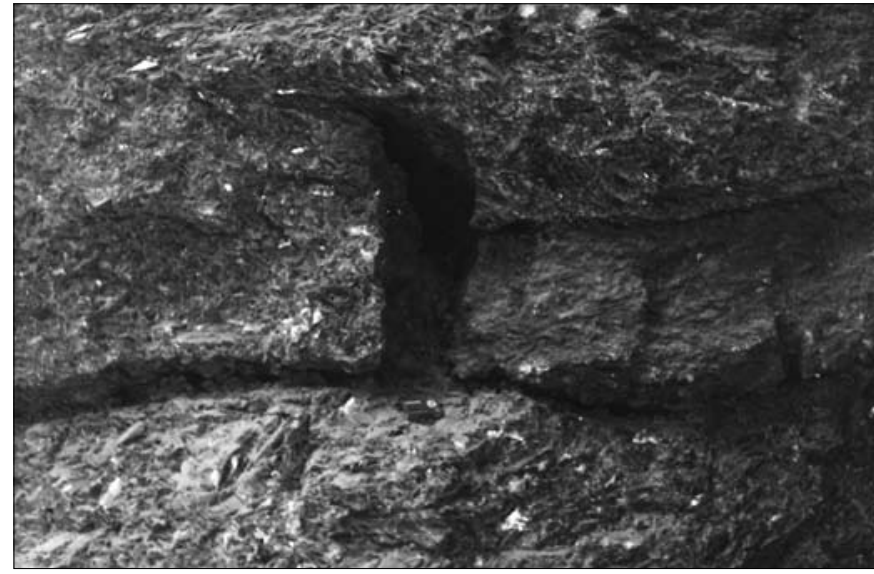

a

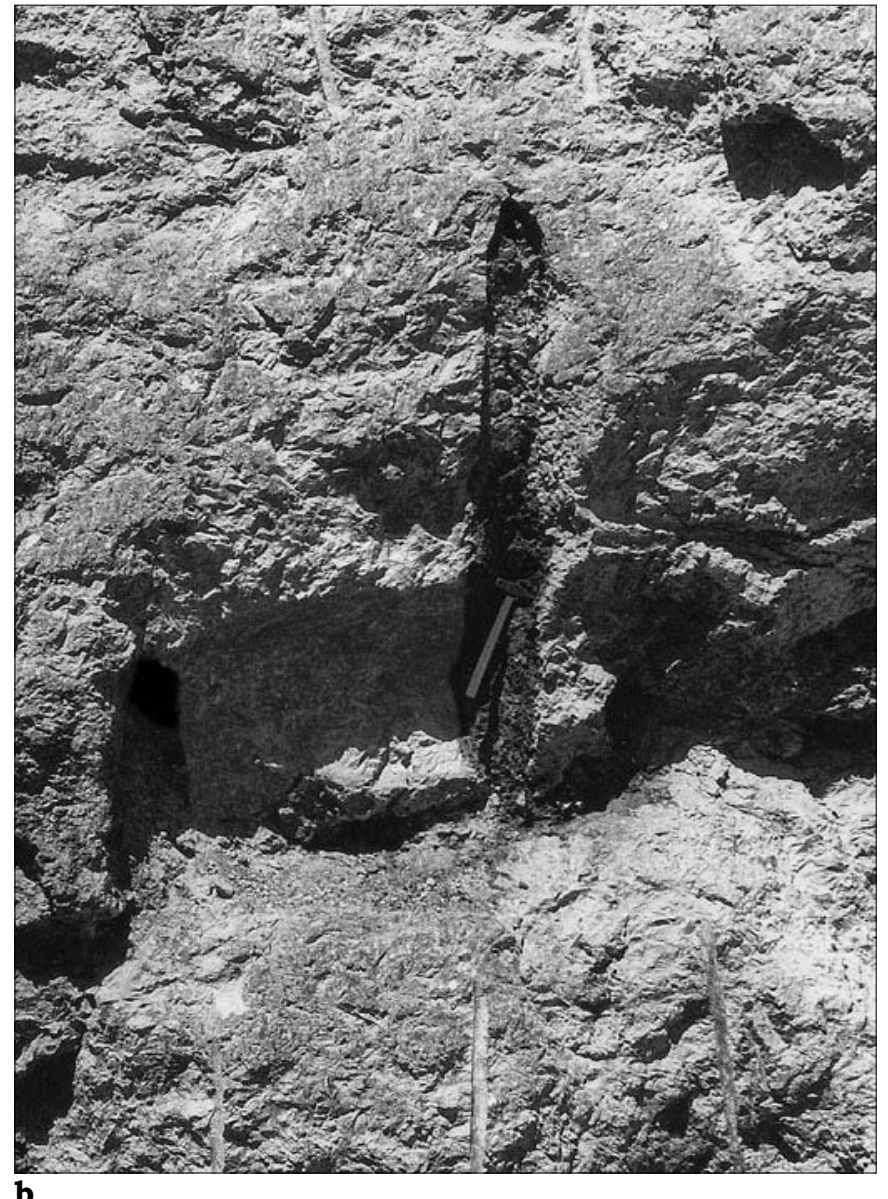

b

Fig. 2 - a) "Antigravitative groove", partially filled with alluvial clayey silt, carved in the messinian selenitic gypsum of the "Fiorini Quarry" (II Farneto, Bologna, Italy). At first, a small phreatic conduit originated in correspondence of a subhorizontal joint plane, clearly visible in the picture. Afterwards the phreatic water, circulating under pressure in the small conduit, was forced by the alluvial deposits piled up on its floor to flow at ever higher levels, engraving only the ceiling and the upper walls of the conduit. This antigravitative groove is about $1 \mathrm{~m}$ high. b) Perfect "antigravitative groove", completely filled with alluvial clayey silt including rare rounded pebbles, carved in the messinian selenitic gypsum of the "Fiorini Quarry" (II Farneto, Bologna, Italy). Also in this case a small phreatic conduit originated in correspondence of a subhorizontal joint plane, clearly visible in the picture. It should be noted that there are neither bedding planes nor fractures near the top of the groove. At the left of the bigger groove, a smaller groove, only partially filled with sediments, is visible. For further explanations see Fig. 2 a. The bigger antigravitative groove is $150 \mathrm{~cm}$ high and $15-20 \mathrm{~cm}$ wide, the smaller is $65 \mathrm{~cm}$ high. vault and sometimes in the uppermost walls, whereas the floor is formed by poorly soluble sediments (Fig. 1, Sez. BB' and CC').

The antigravitative erosion process - if the conditions remain unaltered - ends when the vault of the antigravitative passage becomes tangent to the water table ( = piezometric surface; Fig. $1 \mathrm{c})$.

The vaults of the antigravitative passages are generally semicircular or arched in cross-section (Fig. 3), and sometimes - when the water free-face remained for a long time tangent to the vault - they are flat and subhorizontal, because they were "cut" by the surface of the water.

In a subsequent phase the filling can be partially or totally removed by a vadose stream, that can also more or less modify the antigravitative passage's morphology.

One or more cycles of sediment filling, antigravitative erosion and partial or total sediment flushing are clearly recorded in several caves.

Most antigravitative passages are at present flooded or obstructed by the filling (which sometimes chokes the whole passage, as far as the vault): therefore they are not explored, and frequently they go unnoticed . An antigravitative passage becomes visible mainly:

- when it is intersected by a more recent, vadose and passable canyon;

- as a consequence of a collapse in an adjacent room or passage;

- when it is intersected by a quarry (see Fig. 4a, b) or other man-made excavation.

An antigravitative passage becomes practicable, owing to a lowering of the water table, when:

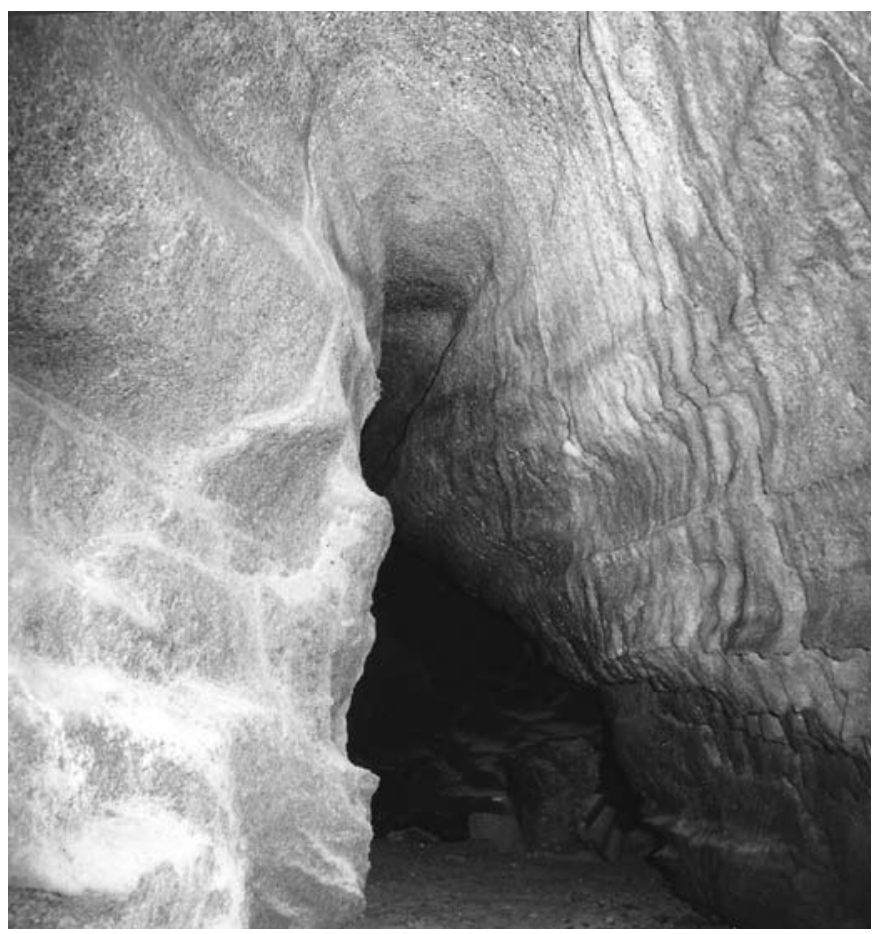

Fig. 3 - "Antigravitative canyon" of the "Grotta del Tunnel", cave carved in the messinian selenitic gypsum near "Il Farneto" (Bologna, Italy) (Photo Edoardo Altara). This antigravitative canyon was only partially emptied of the alluvial filling by a vadose stream: the floor of the passage is formed by clayey-sandy sediments, which constitute the top of the residual filling. This passage is about $5 \mathrm{~m}$ high. 


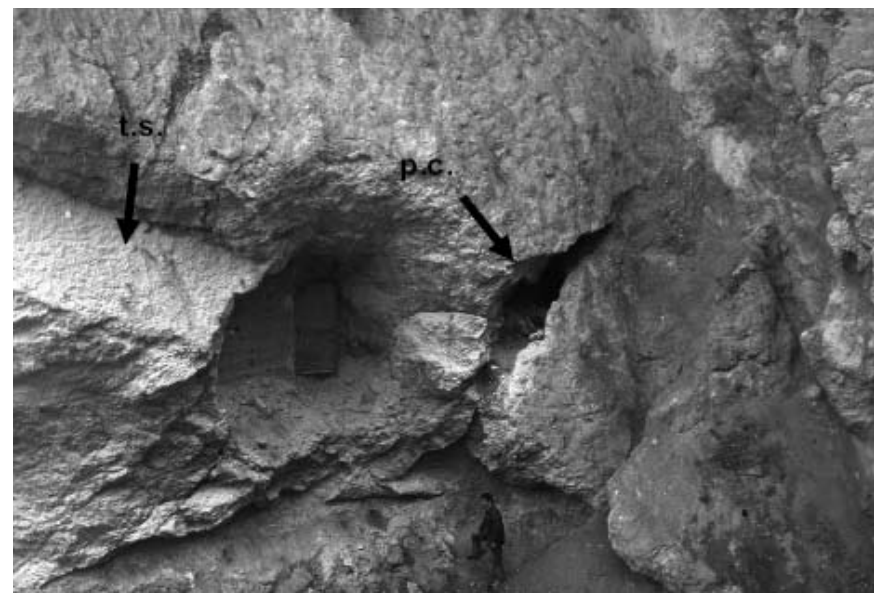

Fig. 4 - a) Entrance of the "Buco delle gomme" (Photo Edoardo Altara), a subhorizontal cave in the selenitic gypsum near "Il Farneto" (Bologna, Italy) excavated by the antigravitative erosion (see crosssection AA' in Fig. 4 b). Under the passable cave ( marked by "p. c.") the topmost portion of a big gallery completely filled by alluvial sediments and accidentally sectioned by a quarry is clearly visible. The filled gallery joins upwards the passable cave. The filling consists mainly of sandy clays, covered by a thin bed of gravel (see Fig. 4 b). The blocks of rock visible at the left of the man are due to very recent collapses. The whitish rectangular surface to the left of the door is the top of a stratum (marked by "t. s."), and evidences that the bedding planes are steeply dipping (see Fig. 4 b). The dimensions of the visible portion of this antigravitative cave are: more than $8 \mathrm{~m}$ in heigth, more than $14 \mathrm{~m}$ in breadth; the filling is more than $5,5 \mathrm{~m}$ thick.

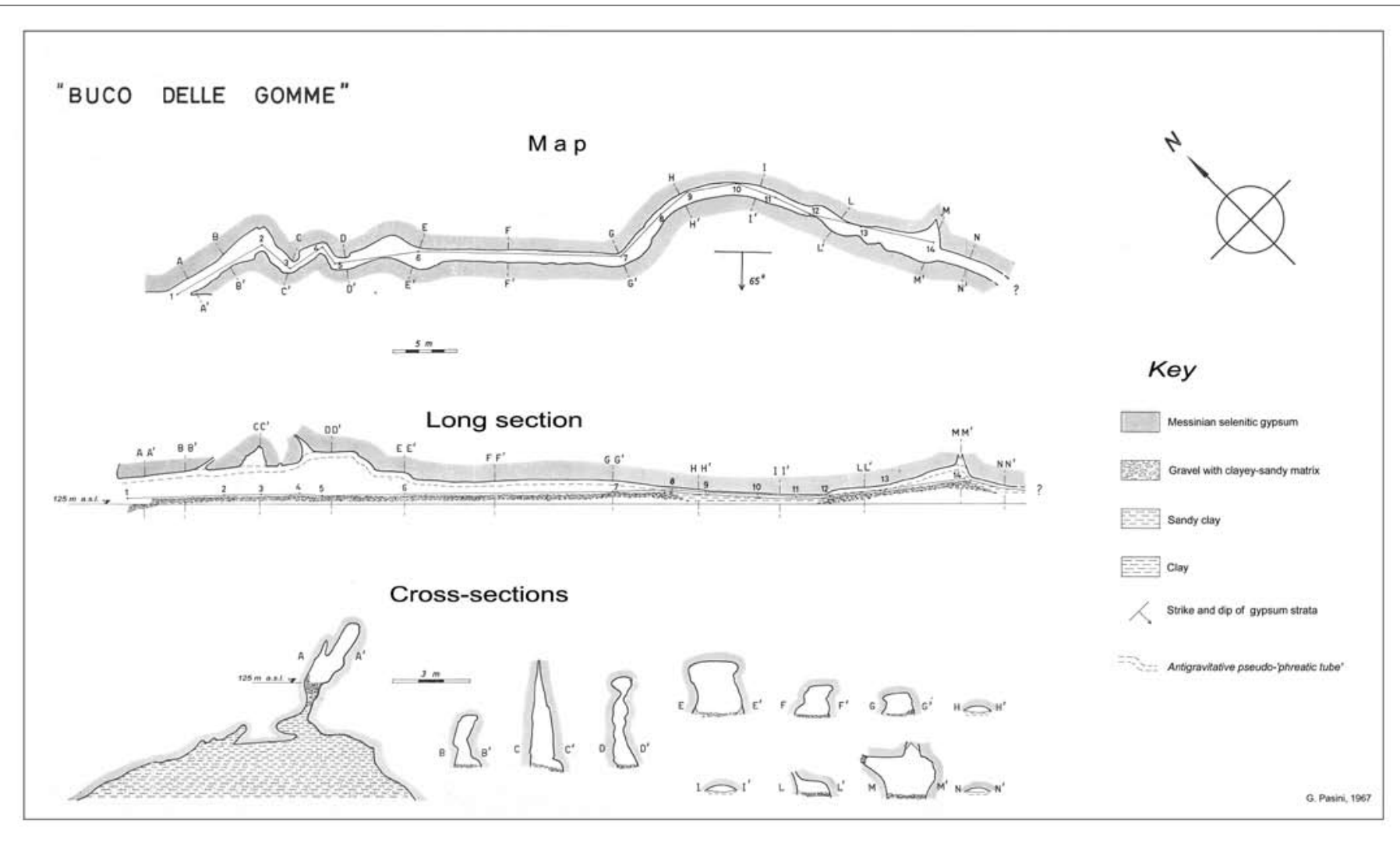

Fig. 4 b) Map, long section and cross-sections of the "Buco delle gomme". When the cave was in the stage of antigravitative evolution represented in Fig. $1 \mathrm{~b}$, the piezometric surface sank, and vadose conditions were established. Vadose waters removed part of the filling, leading the cave to the present conditions. Cross-section AA' corresponds practically to Fig. 4 a. (From Pasini 1967b, modified).

- it dries up, and the space between the filling's top and the vault is big enough to allow the passing of a man;

- it turns into a vadose passage, and the vadose stream removes totally or partially the filling (see Fig. 3 ), allowing the passing of a man.

Among the speleoforms originated by the antigravitative erosion (see Farrant, 2004) I will take into consideration only the antigravitative canyons and the antigravitative ceiling channels.

\section{Antigravitative canyons}

The antigravitative canyons (= "forre antigravitative" of Pasini, 1975, p. 302) are practicable passages originated by the antigravitative erosion, generally with canyon-like cross-sections (Fig. 3). Their vertical amplitude may exceed $50 \mathrm{~m}$ - as in the cases mentioned by Lauritzen and Lauritsen (1995, p. 56), Ford (2000, p. 323 ) and Ford and Williams $(2007$, p. 232). A very important, diagnostic difference between the vadose canyons and the antigravitative canyons is that in the firsts the guiding bedding-planes or fractures are near the ceiling, whereas in the seconds they are near the floor.

\section{Antigravitative ceiling channels}

They are ceiling channels with semi-circular or arched cross-sections; sometimes they show a flat subhorizontal top (Fig. 5), due to their prolonged tangency to the water table. Not infrequently the antigravitative ceiling channels formed in epiphreatic conditions, because a passage in which flowed a stream was choked with sediments; these sediments compelled the stream, decreased in flow and in 


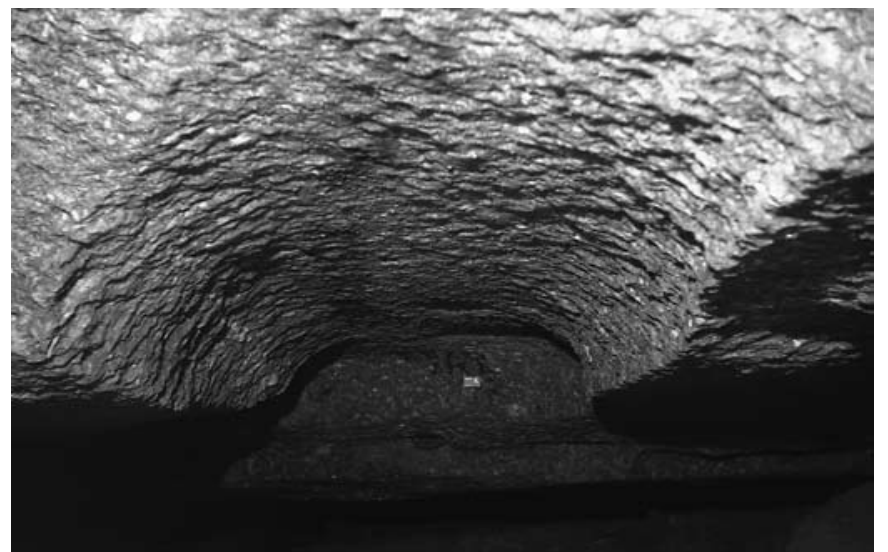

Fig. 5 - Detail of an"antigravitative ceiling channel" with flat top in the "Grotta della Spipola", engraved in the messinian selenitic gypsum of the "Monte Croara" (Bologna, Italy) (Photo Edoardo Altara). This channel is about $110 \mathrm{~cm}$ wide.

width, to run along the sediment-rock interface. The stream being narrower, it could not erode the whole ceiling, but only a limited portion of it, carving an antigravitative ceiling channel. Antigravitative ceiling channels can form also in phreatic conditions (see paragenetic half- tubes in Farrant, 2004, p.570).

Only some ceiling channels are originated from the antigravitative erosion (Pasini, 1967a).

Antigravitative ceiling channels are described, e.g., by: Bretz (1942, p. 740 and fig. 30; 1956, pp. 2223 and fig. 117), Renault (1958, pp. 31-33 and fig. 3 [11] ), Pasini (1966, pp. 1-71, figs. 1-30 and pls. I A-VI; 1967a, pp. 21-27, 30-41, 52-53 and pls. I , III, V, VI; 1967b, pls. I and II), Renault (1968, pp. 568569 and fig. 64), Bini (1979, pp. 38-40 and 4 figs.), Brini and Grimandi (1985, pp. 15-29, figgs. 1-3 and photographs 1-2) Ford and Williams (1989, p. 296), Lauritzen and Lauritsen (1995, p. 55 and fig. 1 [h] ), Calaforra (1998, pp. 153-157, pl. VIII [1,2] and fig. II. 35), Lauritzen and Lundberg (2000, p. 419, 6.1. fig.8 [c]), Forti (2000, fig. 15), Farrant (2004, p. 570 and fig. "Paragenesis"), Ford and Williams (2007, p. 232).

Some caves engraved in various kinds of karstifiable rocks and showing outstanding antigravitative erosion phenomena are mentioned in Table I.

\section{RECOGNIZABILITY OF ANTIGRAVITATIVE CAVES}

Lowe and Waltham (1995), in the "Dictionary of Karst and Caves" (p. 26), wrote what follows:

"Paragenesis: A type of cave passage development in which erosion of the passage floor is inhibited by the presence of an armoring layer of sediment, such that any dissolutional enlargement is dominantly upwards".

"Paragenetic cave: Cave passage, usually of canyon form, believed to be created by paragenesis. Passage formation by paragenesis is normally very difficult to prove, as later sediment removal leaves a passage that looks very similar to the far more common vadose canyon." (italics added).

Field (2002), in the "Lexicon of Cave and Karst Terminology with Special Reference to Environmental Karst Hydrology", reported verbatim the definitions of "Paragenesis" and "Paragenetic cave" of Lowe and
Waltham (1995), and added also to the definition of "Paragenesis" the following sentence (p. 135):

"Paragenesis] - Generally, an unproven and unsupported theory".

As a matter of fact, the paragenesis (that from now onwards should be named antigravitative erosion, as it has been suggested above) is a kind of corrosional and erosional evolution of some cave passages wellknown at least since 1942, proven and supported by tens of examples throughout the world (see, e.g., Table I and Figs. 2 to 6). The great number of caves which developed through antigravitative erosion in different bedrocks cropping out in several regions of the world, and the large or huge dimensions of some of them, testify that the antigravitative erosion is a frequent and important speleogenetic process.

Moreover, after reading almost all the papers written on this topic, I underline that it is incorrect to say that "passage formation by paragenesis is normally very difficult to prove".

Indeed, the speleoforms due to the antigravitative erosion are rather easily recognizable for at least four reasons:

1) At times some branches of the caves enlarged by the antigravitative erosion and entirely preserving their fill and their morphology are intersected by other more recent, vadose and passable branches. The filled branches can be intersected also by quarries (Figs. 2 a-b, 4 a). Such intersections highlight clearly the features and the development of the antigravitative galleries.

2) Some passages of karstic caves were, in sequence:

a) excavated as phreatic tubes along bedding planes or fractures of the bedrock;

b) almost completely filled by fine-grained sediments, and contemporaneously engraved upwards by the antigravitative erosion, forming antigravitative canyons.

c) at last, not infrequently emptied of the filling by vadose streams ("recreusement" of Renault, 1968, p. 587), that sometimes enlarged and modified the antigravitative canyons.

But the antigravitative canyons are not always totally emptied of the filling by the vadose erosion: some remnants ("témoins cimentés" of Renault 1968, p. 588) of the former filling stick often to the ceiling, testifying that these passages were previously antigravitative canyons (see, e. g., Renault, 1961, p. 64 ).

3) Even if an antigravitative canyon was entirely emptied of sediments by a vadose stream, unless this canyon has been completely modified by the vadose erosion, it is generally possible to recognize its antigravitative history. Let's consider - for simplicity reasons - an antigravitative canyon with "keyhole" crosssections (see Fig. 7a, b, although this figure represents small, non enterable caves, and not canyons). First of all - as I said above - the bedding-planes and fractures along which the oldest parts of this canyon developed ("guiding bedding-planes and fractures") are located near the floor - whereas in a vadose canyon they are located near the vault. Moreover, in this antigravitative 
Table 1. Examples of karstic caves which show outstanding antigravitative erosion phenomena. For each cave are indicated: the rock in which the cave is excavated, the country in which the cave is located, its main antigravitative features (when possible), the author (or authors) who mentioned the cave in a paper (or papers), the year (or years) of publication of that paper, and the pages, figures and plates of that paper in which the antigravitative erosion phenomena are described or represented. Well developed antigravitative erosion phenomena have been observed also in the karst of Cuba, Jamaica and other humid tropical regions (Lehmann, quoted by Gèze, 1961, pp. 79-80).

\begin{tabular}{|c|c|c|c|c|c|}
\hline Name of the cave & Country & Antigravitative speleoforms & Author(s) & Year(s) & Page, fig., pl. \\
\hline \multicolumn{6}{|c|}{ Caves in limestones } \\
\hline $\begin{array}{l}\text { Paläotraun of } \\
\text { Eisriesenwelt }\end{array}$ & Austria & $\begin{array}{c}\text { "spectacular example of such passages" [antigra-vitative } \\
\text { canyons] }\end{array}$ & $\begin{array}{l}\text { Lauritzen and } \\
\text { Lundberg }\end{array}$ & 2000 & p. 414 \\
\hline $\begin{array}{l}\text { Grotte de Bara- } \\
\text { Bahau } \\
\end{array}$ & Dordogne, France & $\begin{array}{l}\text { in this cave there are antigravitative passages } 10 \mathrm{~m} \text { wide } \\
\text { and } 5 \mathrm{~m} \text { high, and a sandy filling more than } 20 \mathrm{~m} \text { thick }\end{array}$ & Renault & 1961 & p. 62 \\
\hline Grotte de Cantal & France & antigravitative gallery $10 \mathrm{~m}$ wide & Renault & 1968 & p. 583 \\
\hline Grotte de Cougnac & Lot, France & $\begin{array}{l}\text { in this cave there are antigravitative galleries where the } \\
\text { filling is more than } 8 \mathrm{~m} \text { thick }\end{array}$ & Renault & 1968 & p. 583 \\
\hline Grotte de Miremont & France & antigravitative gallery at least $10 \mathrm{~m}$ wide & Renault & 1968 & p. 580 \\
\hline Grotte de Pécherey & France & & Renault & 1968 & p. 580 \\
\hline $\begin{array}{l}\text { Grotte du Cap de la } \\
\text { Bouiche }\end{array}$ & Ariège, France & antigravitative gallery more than $10 \mathrm{~m}$ wide & Renault & 1968 & p. 580 \\
\hline $\begin{array}{l}\text { Réseau de l'Aven } \\
\text { d'Orgnac }\end{array}$ & France & $\begin{array}{l}\text { "....pourrait être cité comme example spectaculaire d'une galerie } \\
\text { paragénétique de dimensions exceptionnelles" [could be } \\
\text { mentioned as spectacular example of paragenetic gallery } \\
\text { with exceptional dimensions] }\end{array}$ & Renault & 1968 & p. 581 \\
\hline $\begin{array}{l}\text { Grotta N.3 and Grotta } \\
\text { N. } 6 \text { di Cala di Luna }\end{array}$ & Sardinia, Italy & $\begin{array}{c}\text { in these caves there are well developed antigravitative } \\
\text { ceiling channels (fig. 6) }\end{array}$ & Pasini & 1975 & p. 304 \\
\hline Svaritsen & $\begin{array}{l}\text { North } \\
\text { Norway }\end{array}$ & & $\begin{array}{l}\text { Lauritzen and } \\
\text { Lundberg }\end{array}$ & 2000 & 6.1. pl.6. \\
\hline Karlovice system & Slovenia & & Šušteršič & 2006 & p. 5 \\
\hline $\begin{array}{l}\text { Flint Mammoth Cave } \\
\text { System }\end{array}$ & Kentucky, U.S.A. & & $\begin{array}{l}\text { Bretz } \\
\text { Ford and } \\
\text { Ewers } \\
\text { Lowe and } \\
\text { Waltham }\end{array}$ & $\begin{array}{r}1978 \\
1995 \\
\end{array}$ & $\begin{array}{l}\text { p. } 232 \\
\text { p. } 26\end{array}$ \\
\hline Pike's Peak Cave & Missouri U.S.A. & & Bretz & 1956 & fig. 117 \\
\hline Seawra Cave & $\begin{array}{l}\text { Pennsylvania } \\
\text { U.S.A. }\end{array}$ & & Bretz & 1942 & p. 736 \\
\hline Wonder Cave & Tennessee U.S.A. & & Bretz & 1942 & p. 736 \\
\hline Endless Caverns & Virginia, U.S.A. & & Bretz & 1942 & p. 736 \\
\hline $\begin{array}{l}\text { Bambuí Karst (Lagoa } \\
\text { Santa Area) }\end{array}$ & $\begin{array}{l}\text { Minas Gerais, } \\
\text { Brazil }\end{array}$ & & $\begin{array}{l}\text { Auler \& } \\
\text { Farrant }\end{array}$ & 1996 & p. 190 \\
\hline Jenolan Caves & $\begin{array}{c}\text { New South } \\
\text { Wales, Australia }\end{array}$ & & Osborne & 1999 & pp.18-19 fig.11 C \\
\hline \multicolumn{6}{|c|}{ Caves in marble } \\
\hline Storsteinshola & North Norway & $\begin{array}{c}\text { "...spectacular example of such passages" [antigra- vitative } \\
\text { canyons] }\end{array}$ & $\begin{array}{l}\text { Lauritzen and } \\
\text { Lundberg }\end{array}$ & 2000 & p. 414 \\
\hline \multicolumn{6}{|c|}{ Caves in gypsum } \\
\hline Buco delle Gomme & $\begin{array}{l}\text { Emilia Romagna, } \\
\text { Italy }\end{array}$ & $\begin{array}{l}\text { fully antigravitative cave, with a filling more than } 5,5 \mathrm{~m} \text { thick } \\
\text { (fig. } 4 \mathrm{a}, \mathrm{b} \text { ) }\end{array}$ & Pasini & $\begin{array}{l}19661967 a \\
1967 b 1975\end{array}$ & $\begin{array}{l}\text { pp. } 33-34 \text { pp. } 33-34 \\
\text { pp. } 83-86 \text { p. } 299\end{array}$ \\
\hline $\begin{array}{c}\text { Acquafredda- } \\
\text { Spipola Cave System }\end{array}$ & $\begin{array}{l}\begin{array}{c}\text { Emilia Romagna, } \\
\text { Italy }\end{array} \\
\end{array}$ & $\begin{array}{l}\text { in just one room of this cave there are all of } 12 \text { ceiling } \\
\text { channe/s, mostly antigravitative (fig. } 5 \text { ) }\end{array}$ & Pasini & $\begin{array}{l}19661967 a \\
1967 b 1975 \\
\end{array}$ & $\begin{array}{l}\text { pp. } 17-31 \text { pp. } 21-32 \\
\text { pp. } 83-86 \text { p. } 299\end{array}$ \\
\hline Grotta del Tunnel & $\begin{array}{l}\text { Emilia Romagna, } \\
\text { Italy }\end{array}$ & $\begin{array}{c}\text { in this cave an outstanding example of antigravitative } \\
\text { canyon is visible (fig. 3) }\end{array}$ & Pasini & $\begin{array}{c}1967 a \\
1967 b 1975\end{array}$ & $\begin{array}{l}\text { pp. } 34-41 \text { pp. } 83-86 \\
\text { p. } 299\end{array}$ \\
\hline $\begin{array}{l}\text { Covadura Cave } \\
\text { System }\end{array}$ & $\begin{array}{c}\text { Sorbas, } \\
\text { Andalusia, Spain }\end{array}$ & & $\begin{array}{l}\text { Calaforra and } \\
\text { Pulido-Bosch }\end{array}$ & 2003 & fig. 2 \\
\hline \multicolumn{6}{|c|}{ Caves in salt } \\
\hline Sedom Cave & Israel & & Frumkin & 1998 & p. 190 \\
\hline
\end{tabular}

canyon the topmost gallery (with sub-circular crosssections) has, as a rule, topographic axes that are quite independent of - and often unconformable with - the bedding planes, the joint planes and the fault planes of the bedrock (Pasini, 1967b, p. 87; 1975, pp. 297, 299 and 301). Obviously, these observations can be made also for canyons not having "keyhole" cross-sections (see Figs. 1 and 3).

4) The diagnostic differences between scallop and meander morphometry have been studied by Lauritzen and Lauritsen (1995), and developed into a method by which paragenetic and vadose canyons can be distinguished (Fig. 8).

\section{CONCLUSIONS}

The antigravitative erosion is an important morphogenetic process which acts only underground, more exactly in the karstic caves. Thus the "antigravitative erosion" is a phenomenon exclusive of karstic caves and unique in nature. 


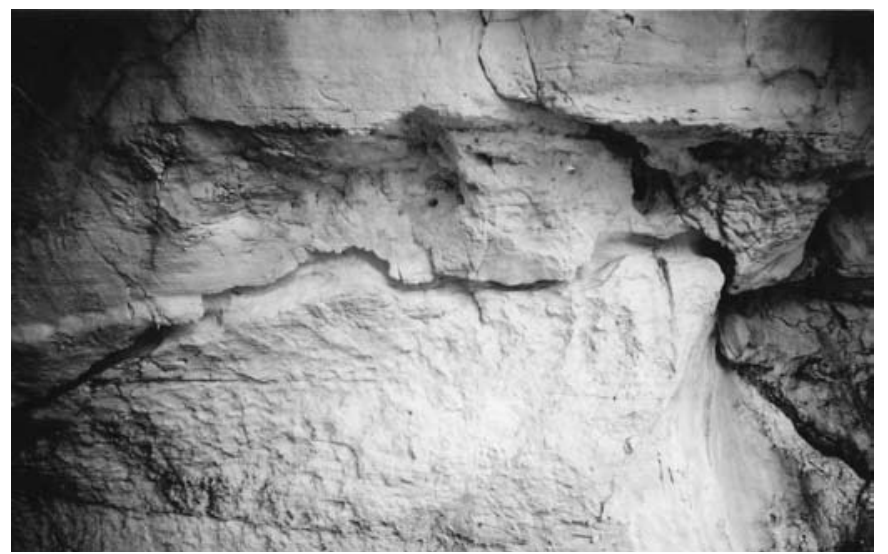

Fig. 6 - Part of an "antigravitative ceiling channel" in the vault of the "Grotta N. 3 di Cala di Luna" (eastern Sardinia Island, Italy), cave carved in jurassic limestones (Photo Elzbieta Horczynska). In this case the filling consisted almost certainly in würmian eolianites, later eroded by the sea. This winding channel is about $15 \mathrm{~cm}$ wide and $12 \mathrm{~m}$ long.
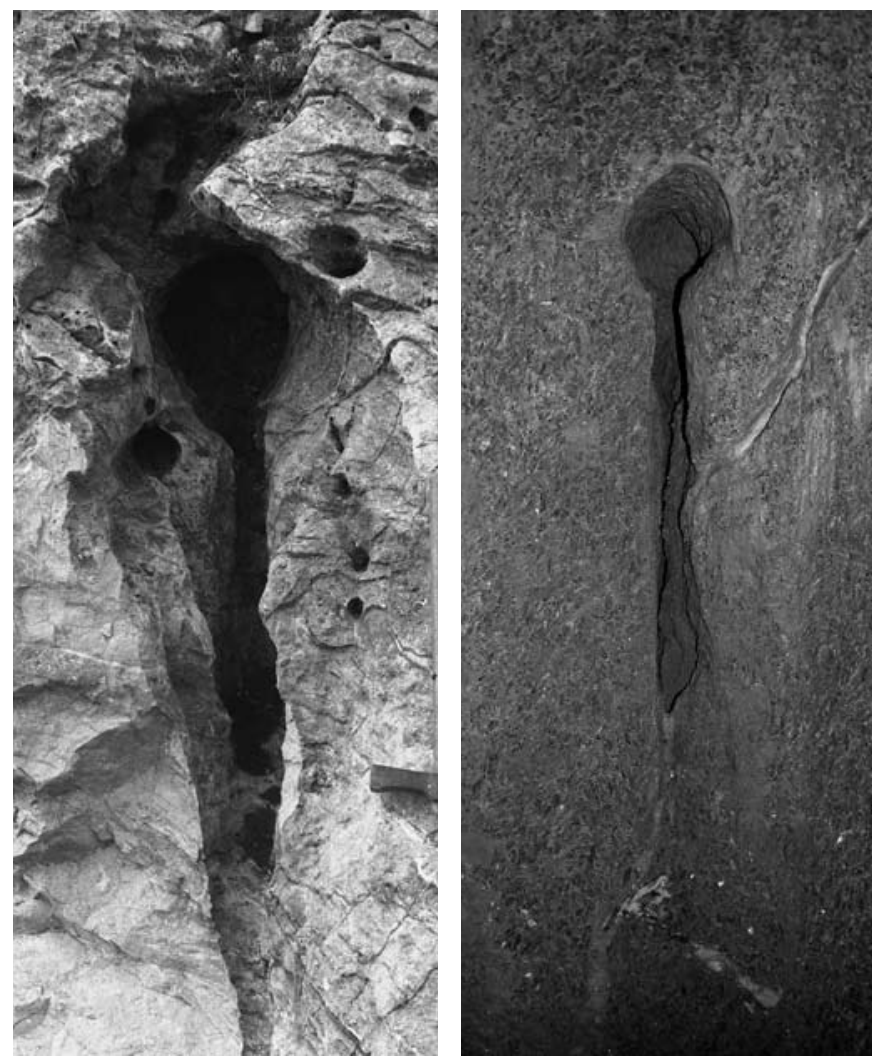

a

b

Fig. 7 - a) "Keyhole" due to normal erosion, carved in the jurassic limestones of "Cala di Luna" (eastern Sardinia Island, Italy) (Photo Luigi Carobene): at first formed the conduit with circular crosssection at the top of the impassable cave, in phreatic conditions; then a small vadose stream carved the floor of the phreatic conduit, forming the vertical fissure below it. So, in this case, the erosion acted top-down (gravitative erosion). This keyhole is about $1 \mathrm{~m}$ high. b) "Antigravitative keyhole" in the "Grotta Novella" (Photo Ugo Calderara), carved in the messinian selenitic gypsum of "II Farneto" (Bologna, Italy), and partially filled with sediments. A small phreatic conduit formed in correspondence with a fracture - visible in the photo -, and then developed upwards by antigravitative erosion: so, at first, formed - because of the ever-growing filling - the fissure with parallel vertical walls, and, at the end, formed the hole with circular cross-section at the top. This keyhole is $90 \mathrm{~cm}$ high. The keyholes of bigger dimensions form in the same ways.

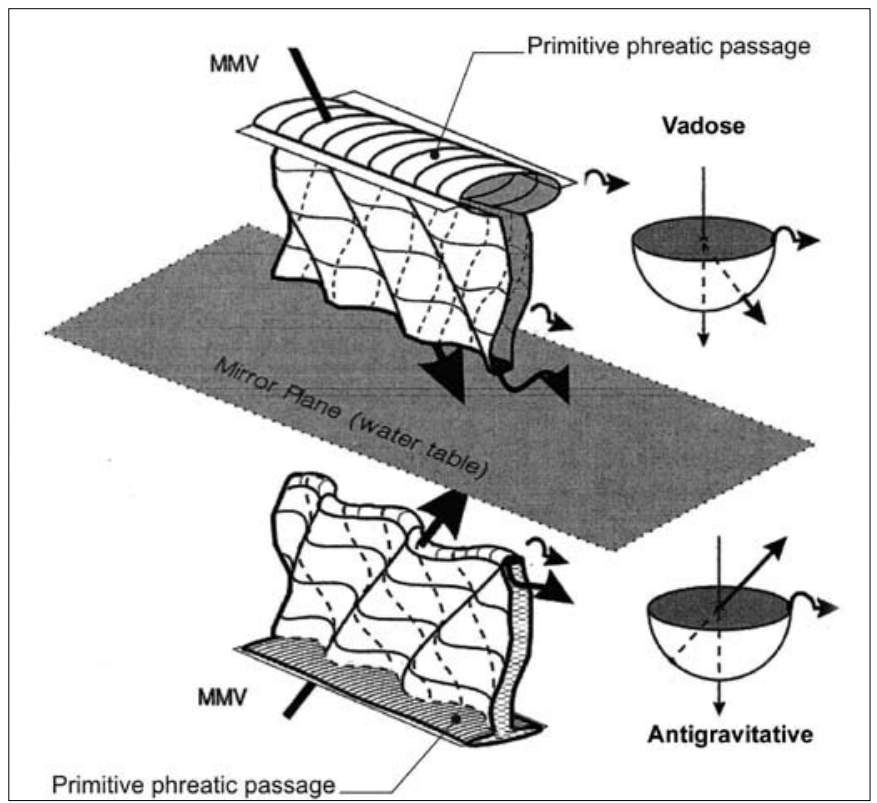

a

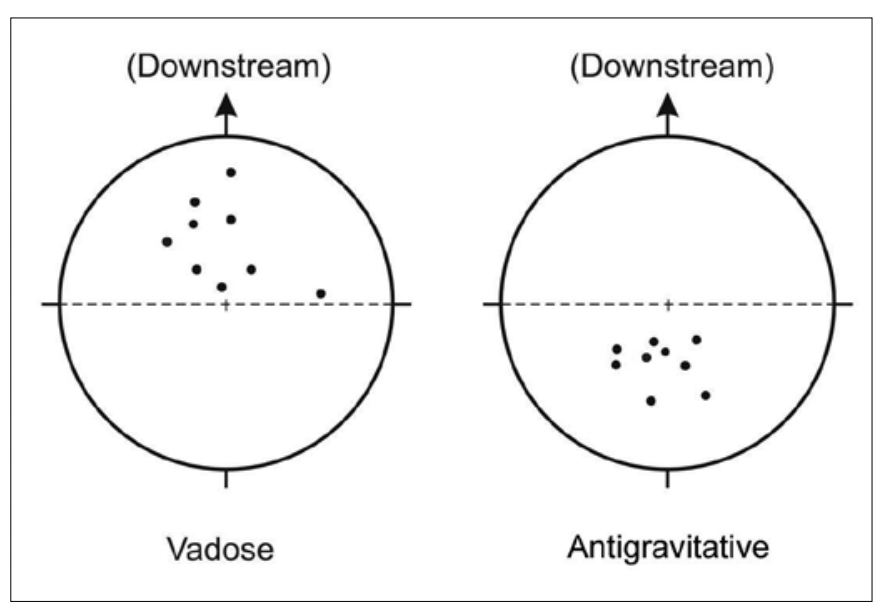

b

Fig. 8 - a) Differential diagnosis between vadose canyons and antigravitative canyons. Vadose entrenching canyons and antigravitative canyons form a pair of mirror images. They are mirrored through the water table. The meander migration vector (MMV) is shown by the heaviest arrows, and it can be determined from canyon walls and scallop-flow direction. The two vectors plot in the upper and lower hemispheres of a stereonet, respectively. When both vectors are projected into a lower hemisphere, scallop flow direction (hooked arrows) and MMV plot differently for the two cases (right). b) MMV plots from Storsteinshola, Kiøpsvik Quarries, north Norway. Left : Present-day active vadose canyon. Right : The suspected antigravitative passage. They plot as indicated in Figure $8 \mathrm{a}$, and confirm the suspicion of an antigravitative origin for the passage. (Figure and figure caption from Lauritzen and Lauritsen 1995, modified, and Lauritzen and Lundberg, 2000, modified).

Concerning the importance of this phenomenon Farrant (2004, p. 571) rightly wrote: "Many caves displaysomeevidenceofeitherparageneticdevelopment or subsequent modification. Its recognition is crucial as vadose and paragenetic passages have very different geomorphic and paleoclimatic implications, yet the true extent and significance of paragenesis and alluviation in speleogenesis and development is probably underestimated. This is partially because by their very nature, most paragenetic caves are 


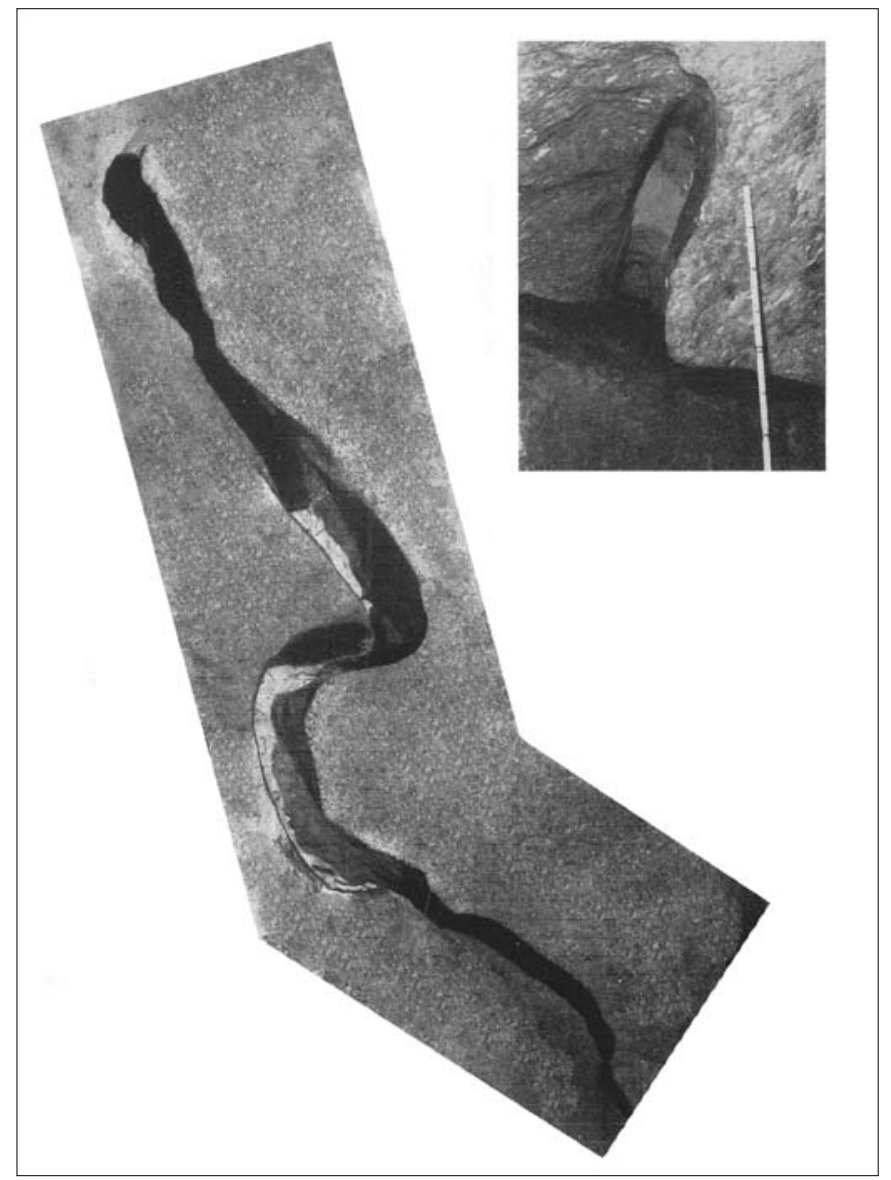

Fig. 9- a) Part of an"antigravitative ceiling channel" in the "Grotte della Spipola", cave engraved in the messinian selenitic gypsum of the "Croara" (Bologna, Italy). The winding channel preserves in some places small portions of its alluvial sandy-clayey fill (whitish zones in the photograph). In this case a little phreatic conduit formed in correspondence of a subhorizontal bedding plane. For further explanations see Fig. 2 a. This antigravitative ceiling channel is about $15 \mathrm{~cm}$ wide and $20 \mathrm{~m}$ long. b) Natural "cross-section" of the antigravitative ceiling channel shown in Fig. 9 a. In this stretch the channel is completely filled with alluvial deposits (sandy clay, sand, gravel and marl). Under the channel the top of the collapsed underlying gypsum bed is visible. The height of the antigravitative ceiling channel in this point is of about $60 \mathrm{~cm}$.

flooded or choked with sediment and thus remain unexplored."

In conclusion, I believe that the terms paragenesis and antigravitational erosion should be replaced by the students of speleomorphology and speleogenesis with the term antigravitative erosion - for reasons of priority, etymology and physical meaning - , and that the attributes paragenetic and antigravitational should be replaced with the attribute antigravitative. I think that also the terms syngenesis and syngenetic - in the meaning proposed by Renault (1968) - should be forsaken.

Moreover, I remind that the phenomena due to the antigravitative erosion are easily recognizable in several caves carved in different karstifiable rocks of various parts of the world, and that they are widely proven and quite supported.

\section{ACKNOWLEDGMENTS}

This paper is dedicated to Elzbieta and to Giuseppe
Berti Ceroni. I am indebted to Paolo Grimandi and to other members of the Gruppo Speleologico Bolognese del Club Alpino Italiano - Unione Speleologica Bolognese, who were my companions in several caves. Special thanks are due to Silvio Bergia, Sylvie Braibant and Paolo Giacomelli (Dipartimento di Fisica dell'Università di Bologna), who helped me in clarifying the difference between the physical terms gravity and gravitation, and to Camillo Neri (Dipartimento di Filologia Classica e Medioevale dell'Università di Bologna) for the precious suggestions concerning the etymology of some words deriving from classical Greek. I thank Michele Sivelli (Istituto Italiano di Speleologia, Sezione dell'Istituto di Geologia e Paleontologia dell'Università di Bologna) for the bibliographic material placed at my disposal. I thank also Claudio Busi, Enrico Craici and particuraly Max Cerino for their invaluable technical assistance.

\section{REFERENCES}

Auler A. \& Farrant A.R., 1996 - A brief introduction to karst and caves in Brazil. Proc. Univ. Bristol Spelaeol. Soc., 20 (3): 187-200.

Bini A., 1979 - I canali di volta. Speleologia, 1: 38-40. Bretz J.H., 1942 - Vadose and Phreatic features of limestone caverns. Journal of Geology, 50(6): 675811.

Bretz J.H., 1956 - Caves of Missouri. Geological Survey and Water Resources, 2(39): Rolla, Missouri, 491 p.

Brini M. \& Grimandi P., 1985 - Osservazioni sulla morfologia dei grandi canali di volta presenti nella "Galleria della dolina interna ", nella "Grotta della Spipola" (Bologna, Italia) ; Nota preliminare. Sottoterra, 72: 15-29.

Calaforra J.M., 1998 - Karstología de yesos. Ciencia y tecnología, Monografias, 3. Univ. de Almería, Serv. de Publ., Almería, Spain, 389 p.

Calaforra J.M. \& Pulido-Bosch A., 2003 -Evolution of the gypsum karst of Sorbas (SE Spain). Geomorphology, 50 : 173-180.

Farrant A., 2004. Paragenesis. In: Gunn J. (Ed.), Encyclopedia of Caves and Karst Science. Fitzroy Dearborn, New York - London: 569 - 571.

Field M.S., 2002 - A Lexicon of Cave and Karst Terminology with Special Reference to Environmental Karst Hydrology. U.S. Environmental Protection Agency Report EPA/600/R-02/003/February 2002 (Supercedes 1999 edition) - U.S. Environmental Protection Agency, Washington, DC. [EPA's PDF version (2.4 MB)], (Karst Waters Institute's PDF version (724 KB)). I - VI + $1-214$ pp. (Digital Version).

Ford D.C., 2000 - Speleogenesis Under Unconfined Setting. In : Klimchouk A.B., Ford D.C., Palmer A.N. \& Dreybrodt W. (Eds.), Speleogenesis: Evolution of Karst Aquifers. National Speleological Society, Huntsville, Alabama: 319-324.

Ford D. C. \& Ewers R.O.,1978 - The development of limestone cave systems in the dimensions of length and depth. International Journal of Speleology, 10(3-4): 213-244. 
Ford D.C. \& Williams P., 1989 - Karst Geomorphology and Hydrogeology. Unwin Hyman, London, 585 p.

Ford D.C. \& Williams P., 2007 - Karst Hydrogeology and Geomorphology. John Wiley and Sons, Chichester, UK: $562 \mathrm{p}$.

Forti P. , 2000 - I depositi chimici presenti nella Grotta Calindri. Sottoterra, 110: 31-41.

Freud S.,1921 - Massenpsychologie und Ich-Analyse. Internationaler Psychoanalytischer Verlag, Zurich : 140 p..

Frumkin A., 1998 - Salt cave cross-sections and their paleoenvironmental implications. Geomorphology, 23: 183-191.

Gèze B., 1961 - Discussion after the report of Renault, Ph., 1961. Problèmes physiques en relation avec les remplissages naturels des grottes. Atti Symposium Internazionale di Speleologia " Riempimenti naturali di grotte ", Varenna (Como), 1960. Rassegna Speleologica Italiana, 5(1): 79-80.

Goudie A.S., 2004 - Encyclopedia of Geomorphology. Routledge, New York: 1156 p.

Hole F.D., 1968 - Erosion. In: Fairbridge R. W. (Ed.), The Encyclopedia of Geomorphology. Reinhold Book Corp., New York - Amsterdam - London: 317-320.

Howell J.V., 1957 - Glossary of Geology and related Sciences. Williams \& Heinz Lith. Corp., Washington: 325 p.

Krause M., 1999 - Lexicon für höhlenforscher. Nubuk, 99, 1-214.

Kyrle G., 1923 - Grundriss der theoretischen Speläologie. Österreich. Staatsdruckerei, Wien: 353 p.

Lauritzen S.-E. \& Lauritsen A., 1995 - Differential diagnosis of paragenetic and vadose canyons. Cave and Karst Science, 21(2): 55-59.

Lauritzen S.-E. \& Lundberg J., 2000 - Solutional and Erosional Morphology. In : Klimchouk A.B., Ford D.C., Palmer A.N. \& Dreybrodt W. (Eds.), Speleogenesis: Evolution of Karst Aquifers. National Speleological Society, Huntsville, Alabama: 408-426.

Liddell H.G., Scott R. \& Jones H.S., 1940 - A Greek-English Lexicon. $9^{\text {th }}$ ed. (Suppl.). Clarendon Press, Oxford.

Lowe D. \& Waltham T., 1995 - A Dictionary of Karst and Caves. BCRA Cave Studies Series, 6: 40 p.

Lundberg J., 2005 - Karren. In: Culver D.C. \& White W.B. (Eds.), Encyclopedia of Caves. Elsevier Acad. Press, New York: 315-321.
Maucci W., 1952 - L’ipotesi dell' "erosione inversa " come contributo allo studio della speleogenesi. Bollettino della Società Adriatica di Scienze Naturali in Trieste, 46: 1-60.

Monkouse F.J., 1970 - A Dictionary of Geography, $2^{\text {nd }}$ ed. Edward Arnold Publ. Ltd., London.

Monroe W.H., 1970 - A Glossary of Karst Terminology. U.S.G.S. Water Supply Paper No. 1899-K, U.S. Government Printing Office, Washington, D.C.

Osborne R.A.L., 1999 - The Origin of Jenolan Caves: Elements of a New Synthesis and Framework Chronology. Proc. Linn. Soc. New South Wales, 121: 1-27.

Pasini G., 1966 - I canali di volta nelle grotte carsiche del Bolognese. Nuove ipotesi sulla loro formazione. Graduation Short Experimental Thesis n. ${ }^{\circ}$ 280, Academic Year 1964-1965. Library Dept. Earth and Geoenvironmental Sciences of the Bologna University.

Pasini G., 1967a - Osservazioni sui canali di volta delle grotte bolognesi. Le Grotte d'Italia, 4(1): 17-74.

PasiniG., 1967b-Notapreliminare sulruolo speleogenetico dell'erosione "antigravitativa". Le Grotte d'Italia, 4(1): 75-90.

Pasini G., 1975 - Sull'importanza speleogenetica dell' "Erosione antigravitativa". Atti del Seminario Internazionale di Speleogenesi, Varenna (Como, Italy), 1972. Le Grotte d'Italia, 4(4): 297-322.

Renault Ph., 1958 - Eléments de spéléomorphologie karstique. Annales de. Spéléologie, 13(1-4): 23-48.

Renault Ph., 1961 - Problèmes physiques en relation avec les remplissages naturels des grottes. Atti Symposium Internazionale di Speleologia "Riempimenti naturali di grotte", Varenna (Como, Italy), 1960. Rassegna Speleoleologica Italiana, 5(1): 52 - 81 .

Renault Ph., 1968 - Contribution à l'étude des actions mécaniques et sédimentologiques dans la spéléogenèse. $3^{e}$ partie: Les facteurs sédimentologiques. Annales de Spéléologie, 23(3): 529-596.

Šušteršič F., 2006. Relationships between deflector faults, collapse dolines and collector channel formation: some examples from Slovenia. International Journal of Speleology, 35(1): 1-12.

Veni G., 2005 - Passages. In: Culver D.C. \& White W.B. (Eds.), Encyclopedia of Caves. Elsevier Academic Press, New York: 436-440. 